\title{
Youth perspectives on entrepreneurship in Egypt: Barriers to entrepreneurship as a means to combat youth unemployment
}

Maia Sieverding

Population Council

Follow this and additional works at: https://knowledgecommons.popcouncil.org/departments_sbsr-pgy

Part of the Demography, Population, and Ecology Commons, Family, Life Course, and Society Commons, International Public Health Commons, Labor Economics Commons, and the Work, Economy and Organizations Commons

How does access to this work benefit you? Let us know!

\section{Recommended Citation}

Sieverding, Maia. 2012. "Youth perspectives on entrepreneurship in Egypt: Barriers to entrepreneurship as a means to combat youth unemployment," Survey of Young People in Egypt Policy Brief no. 5. Cairo:

Population Council. 


\section{Survey of Young People in Egypt Policy Brief Series}

\section{YOUTH PERSPECTIVES ON ENTREPRENEURSHIP IN EGYPT: \\ Barriers to Entrepreneurship as a Means to Combat Youth Unemployment}

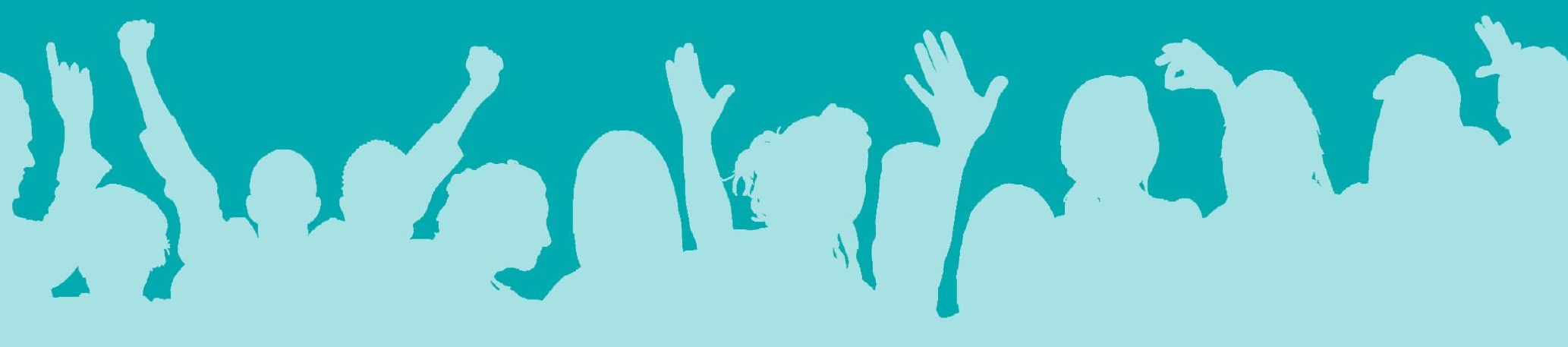

By Maia Sieverding

FORDFOUNDATION Working with Visionaries on the Frontlines of Social Change Worldwide
(2) Population Council Research that makes a difference 
$\mathrm{D}$ evelopment programs in Egypt often encourage entrepreneurship as a means of combating the high level of youth unemployment. However, while over half of Egyptian youth say that they would prefer having their own business to a waged job, very low rates of entrepreneurship are actually observed among young people. Using a combination of quantitative and qualitative data, this brief examines a range of factors that youth perceive to be barriers to starting their own business, including high risk, limited access to finance, complexity of micro-credit schemes, lack of business and marketing training, and need for connections to succeed. These factors combine to create the view among many youth that entrepreneurship is not a viable means of labormarket entry. Rather, youth see entrepreneurship as either a supplemental income-generating activity while also having a "regular" job, or as a later-life employment option once they have established themselves financially or professionally. To promote entrepreneurship as a means of combating youth unemployment, financial and entrepreneurship education, and integrated loan, business information, and marketing services should be promoted.

\section{Key Messages}

- While many youth see self-employment as attractive, few actually start a business.

- Financing is seen as a major difficulty facing youth who want to start a business.

- Youth do not see entrepreneurship as a viable means of labor-market entry, but as something to be done later in life.

- Integrated loan, business, and marketing services are needed for young entrepreneurs.

- Financial and entrepreneurship education should be promoted to reduce fear and misunderstanding of loans, and to help change attitudes toward risk.

\section{Data and methodology}

The recommendations presented in this brief are based on quantitative and qualitative data on youth's perspectives regarding entrepreneurship in Egypt. The quantitative analysis draws on the 2009 Survey of Young People in Egypt (SYPE) ${ }^{1}$, a nationally representative survey of 15,000 youth aged 10-29. The analysis in this brief is restricted

${ }^{1}$ SYPE was conducted in cooperation with the Egyptian Cabinet's Information and Decision Support Center (IDSC) and funded by multiple donors. to youth aged $15-29$, because questions regarding entrepreneurship were not addressed to the younger age group. SYPE included a range of questions regarding entrepreneurial activity among youth, barriers to starting a business, and attitudes toward entrepreneurship. The qualitative analysis is based on focus-group discussions and in-depth interviews conducted with male and female youth aged 15-29, of varying education levels and employment statuses, in Cairo and the three Upper Egyptian governorates of Fayoum, Minya, and Qena. ${ }^{2}$

\section{Entrepreneurship is attractive to many youth in the abstract...}

Entrepreneurship is seen as an attractive employment option by many youth. Just over half of all youth aged 15-29 (53.8\%) said they would prefer to have their own business rather than working for pay. Males were more likely to prefer self-employment; $60.0 \%$ said this would be their preference versus $47.4 \%$ of females. The gender gap in preference for self-employment was slightly larger among those currently in the labor force; $61.4 \%$ of males and $44.0 \%$ of females in the labor force said they preferred self-employment ( $58.4 \%$ overall). The preference for having a business was remarkably consistent across education, residency, and age.

As shown in Figure 1, entrepreneurship is also an attractive option to many youth engaged in other forms of economic activity. Fifty-eight percent of current wage workers said that they would prefer to have their own business. Male wage workers were more likely to prefer having a business, whereas female wage workers and the female unemployed were the least likely to prefer entrepreneurship. The preference for self-employment was also stated among $51.0 \%$ of the unemployed and $71.3 \%$ of unpaid family workers. Not surprisingly, the majority of those who were self-employed or employers preferred their current status. Half of youth who were still in school at the time of the survey also said that they would prefer having a business to a waged job, indicating that entrepreneurship is attractive to future cohorts of labor-market entrants.
The author would like to thank Nahla Hassan for carrying
out the qualitative study of youth entrepreneurship in Upper
Egypt. 
Figure 1: Percent of youth who prefer having a business to working for pay, by gender and current employment status

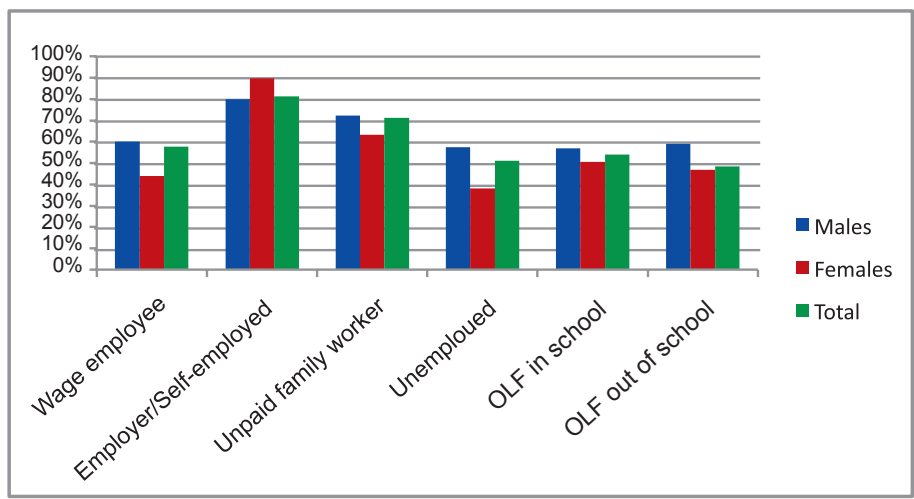

Note: OLF stands for out of labor force.

\section{Youth value the independence of self-employment}

Youth who said they preferred self-employment to a waged job were asked why this was the case. Three reasons dominated their responses. Sixty-eight percent mentioned the greater independence entailed in having a business, while $15 \%$ said that a business would provide a higher income than a regular job, and 9\% mentioned the lack of other job opportunities. Male youth were somewhat more likely to mention greater independence as a reason for preferring entrepreneurship, whereas female youth were more likely to mention more flexible working hours $(4.3 \%)$ and greater career satisfaction (4.9\%). Less than $2 \%$ of male youth mentioned working hours or career satisfaction. Overall these responses suggest that youth value the independence and opportunity that they see in self-employment.

\section{...but very few youth have actually established a business}

Despite the widespread view that starting a business is an attractive option, relatively few youth are actually entrepreneurs or have taken steps toward becoming entrepreneurs. When asked if they had ever thought about establishing a business, $15.5 \%$ said yes, although this rose to $27.9 \%$ among those currently in the labor force. Twenty-three percent of all males had ever thought about establishing a business, compared with $30.0 \%$ of those who were currently in the labor force. The corresponding figures were $7.7 \%$ and $17.9 \%$ among female youth, respectively. The difference between all youth and those in the labor force may be attributable to the fact that a large percent of the former group is still in school and may have thought less about work options. The low labor-force participation rate among female youth may also contribute; deciding to enter the labor market at all is an important first step for young women in thinking about whether or not to start a business.
A considerably smaller percentage of youth, a mere $1.2 \%$ (3.0\% of those in the labor force), actually had a business at the time of the survey. Two percent of all male youth had a business, or $3.2 \%$ of male youth in the labor force. Although only $0.3 \%$ of female youth had a business, this rose to $2.2 \%$ of female youth who were currently in the labor force. Comparing the figures for youth who have thought about starting a business and those who actually have suggests, first, that there is a large pool of male youth who are interested in the idea of starting a business but have thus far not been able to do so. Second, while interest in entrepreneurship is certainly lower among female youth, general barriers to labor-force participation among this group also appear to play a role in reducing entrepreneurial activity.

The motivations of youth who have actually started a business match closely with the advantages that other youth see in self-employment (Figure 2). Approximately a third of youth entrepreneurs opened a business because they could not find wage work, indicating that high unemployment and difficult labor-market conditions do push some youth into entrepreneurship. More than half of male entrepreneurs cited greater independence, compared with $36 \%$ of female entrepreneurs. Nine percent of female entrepreneurs mentioned more flexible hours, a reason that was also more commonly given among female youth who said they prefer selfemployment. This suggests that owning a business may be an attractive way for some female youth to balance work and family responsibilities.

Figure 2: Why youth entrepreneurs chose selfemployment, by gender

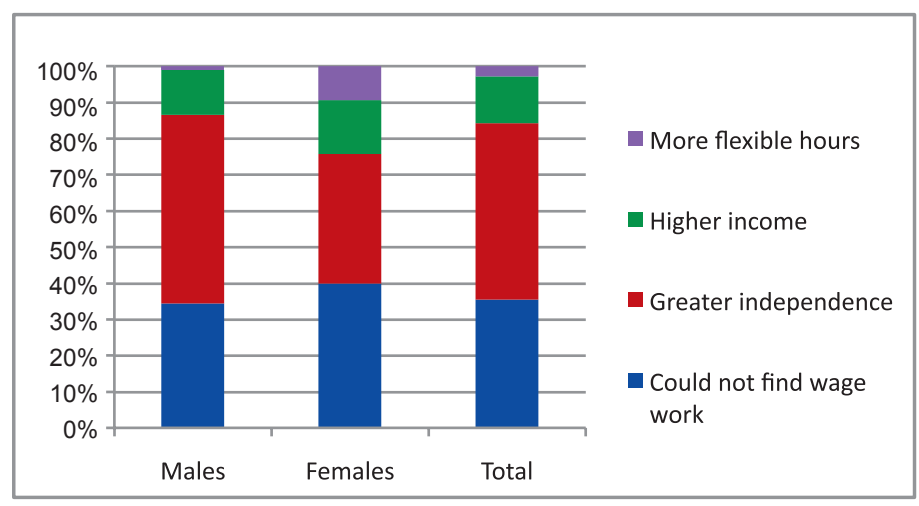

\section{Financing is a major concern for youth interested in starting a business}

Why are there so few youth entrepreneurs if so many find the idea attractive? The answer lies in the barriers that youth perceive and experience in starting a business, particularly in terms of financing. 
All youth surveyed in SYPE were asked what might prevent them from starting a business. Whereas less than $2 \%$ of youth mentioned strong competition or lack of demand for their product as a barrier, and only $5 \%$ the workload, $84.9 \%$ mentioned the inability to find financing. In addition, $18.7 \%$ mentioned the fear of losing money or not being able to pay back a loan, $14.6 \%$ lack of skills or experience, and $13.7 \%$ concerns with licensing requirements. These responses suggest that lack of financing, training, and information on how to start a business are perceived as serious problems for youth interested in entrepreneurship.

Youth in the Urban Governorates were particularly likely to be worried about losing money $(27.0 \%)$, but less concerned with finding finance to start the project $(80.4 \%)$ than youth in other regions. Meanwhile, youth in Urban Lower Egypt (20.8\%), Rural Lower Egypt (18.2\%), and the Frontier governorates (19.4\%) were most likely to be worried about lack of skills and experience. Female youth in Lower Egypt (20.4\% in urban areas and 19.8\% in rural areas) were also particularly concerned about being disadvantaged in starting a business because of their gender. Female youth in the Urban Governorates were least likely to be concerned about this issue $(7.8 \%)$. Overall, $14.7 \%$ of female youth were concerned that their gender would serve as a disadvantage in starting a business. These concerns may contribute to the low rate of entrepreneurship among female youth and indicate that gender considerations should be taken into account when designing entrepreneurship support programs.

Qualitative research similarly revealed that financing is seen as a major barrier to entrepreneurship among youth in Upper Egypt. Many youth in these areas simply do not have the financial resources to start a business. Micro-credit schemes, while well known, were poorly understood by some youth and were also widely seen to have several disadvantages, including the small size of the loans, the complexity of the loan process, and the risk entailed in taking a loan in general. Furthermore, while micro-credit schemes were perceived as being largely for women, many female youth in Upper Egypt saw the risk of taking out a loan and starting a business as inappropriate for girls.

On the one hand, youth's concern with financing a new business appears to be well-founded. Only $6.2 \%$ of youth entrepreneurs in SYPE did not need financing to start their business, and only $4.4 \%$ received financing from a source other than personal connections. None had received a loan from a bank or the Social Fund for Development (SFD). The vast majority of youth entrepreneurs therefore relied on personal financing: $58.9 \%$ took money from their own savings, $31.0 \%$ from their family's savings, and $24.7 \%$ took a loan from a family member or friend (multiple sources were possible). Youth entrepreneurs thus appear to have little access to funding for their startup businesses and have to rely primarily on personal networks and family resources.

The qualitative research also makes clear, however, that there are some misunderstandings on the part of youth as to how business financing works, which may prevent them from applying for the credit opportunities that are available. In addition to the confusion about micro-credit, some youth in Upper Egypt thought that in order to take a loan from SFD they would be required to sign a paper forfeiting their right to any future government employment, a step few were willing to take. Officials from SFD explain that this is not the case, however it is true that Egypt's social insurance law makes it impossible for a recipient of an SFD loan to take a government position while he or she is running the business. Lack of clarity regarding such conditions, as well as conditions related to micro-credit loans, discourages youth from taking advantage of existing entrepreneurship support.

\section{Youth entrepreneurs also need business information and marketing services}

In addition to financing, current youth entrepreneurs cited business information, marketing services, and the need for counseling as the three greatest problems they face in running their business (Figure 3). Male entrepreneurs were particularly likely to mention the need for financial services (31.2\%), whereas female entrepreneurs were most likely to say that they lacked business information $(24.7 \%)$. The gender gap in the need for business information (only $12.4 \%$ of male entrepreneurs mentioned this factor) further indicates the need for business support targeted toward female entrepreneurs. Lack of management training was also noted as an impediment to entrepreneurship in the qualitative research.

Figure 3: Most important problem faced by youth entrepreneurs, by gender, percent mentioning each reason

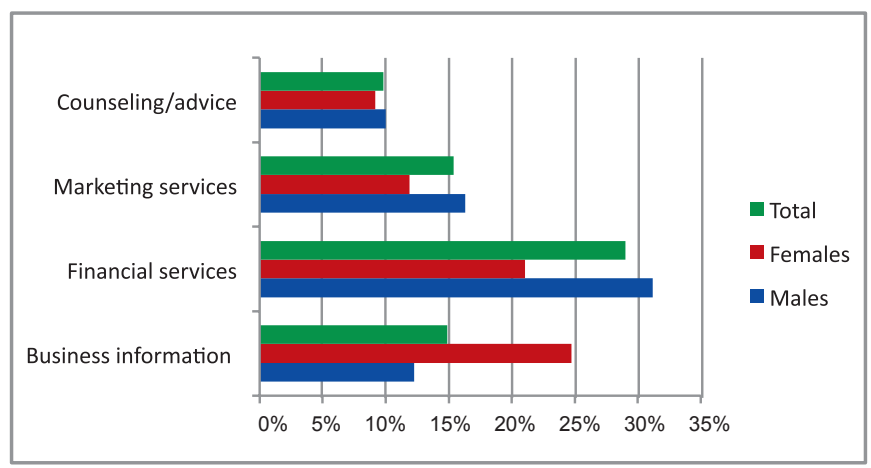




\section{Youth do not see entrepreneurship as a secure means of labor-market entry}

As revealed by the qualitative research, the perceived barriers to entrepreneurship in Egypt contribute to the fact that many youth do not see starting a business as a viable means for starting a career. Rather, they see entrepreneurship as either a supplemental activity to having a regular job or as a later-life employment option once they have established themselves financially or professionally.

Youth were found to make a strong distinction between entrepreneurship, or starting a "project," and regular wage employment, and do not necessarily see these as alternatives to one another. Interviews with youth in Upper Egypt revealed that many saw entrepreneurship not as a substitute for wage employment, but rather as an income-generating activity that could be carried out alongside a job. Notably, some said that this would provide a back-up means of repaying a loan should the business fail.

Youth in Cairo were also concerned with establishing a business before establishing themselves in their field. They saw prior connections in their area of work as essential to the success of any business endeavor. As one young, unemployed female university graduate explained, "I could open a business, but that takes relationships.... To do that, I'd need to work somewhere for two or three years, know where the work comes from and where it goes, and then start something for myself." Likewise, one male university graduate, age 29 , who had established a small trading company, attributed his success to the fact that he had worked as a wage employee in the field for several years before launching his own business. Thus, many youth in Cairo, and particularly young men, said that starting a project is something they would like to do in middle age when they are more established. Such projects were seen as a way to build an incomegenerating venture to provide themselves and their families with a continued source of income in older age, as well as to be more independent than one is as a wage employee.

\section{Policy recommendations}

Unemployment in Egypt is well known to be primarily a youth problem, and particularly a problem of youth labor-market entry (Assaad 2008). Entrepreneurship has been promoted by many development programs as a way to help youth bypass what is often a long and difficult search for wage employment. Entrepreneurship could thus combat youth unemployment while encouraging economic growth. However, many youth do not appear to see starting a business as a viable means of achieving a secure position in the labor market. According to prevailing youth perspectives, entrepreneurship cannot be a solution for unemployment because experience and stability as a wage employee is a prerequisite for successfully starting a business.

A range of policy measures to improve the regulatory environment and support services for youth interested in entrepreneurship have been put forward (see IDRC and PEPRI 2009; UNDP and INP 2010). The findings discussed in this brief emphasize the importance of some of these recommendations, and also suggest others. The findings from this survey suggest that providing youth with solid business skill sets and developing services for young entrepreneurs are two important steps not only in improving the success rate of new enterprises but also in increasing confidence among youth interested in starting a business. The knowledge that they have the skills needed to start a business and that support services exist to provide them with the skills they do not possess can help reduce the fear of risk and instability that many youth associate with selfemployment. It can also help reduce the sense that success in business depends primarily on preexisting networks and financial resources.

An important step toward changing youth's attitudes regarding entrepreneurship is to integrate financial education into intermediate stages of the schooling system for all young people. In addition to providing a valuable life skill, financial education can improve youth's understanding of how loans and other financial services work. This will help reduce misunderstandings and apprehension about using these types of services. In addition, entrepreneurship education should be implemented in universities and post-secondary technical institutes, as well as in vocational secondary schools where many students do not continue on to higher education. Evidence from developed countries indicates that entrepreneurship education at the secondary and post-secondary levels can improve attitudes toward entrepreneurship (GEM 2010).

As noted elsewhere (UNDP and INP 2010), a great need exists for marketing, business information, and management-training support services for youth. The Egyptian government did, in fact, enact a law to support such services: Law 141 of 2004 to promote micro and small enterprises (MSEs). This law tasked the SFD with providing MSEs support in terms of 
identifying investment opportunities and preparing feasibility studies, as well as information on regulations, potential risks, and marketing channels (Attia 2009). However, the fact that youth surveyed in 2009 continue to cite financing and financial risk, skills development, and business information as the main factors that may prevent them from opening a business - and that current youth entrepreneurs do in fact face problems in these areas in addition to that of marketing-clearly suggests that Law 141 has fallen short of its goals.

The results of the survey indicate that in addition to continued efforts to improve business support for MSEs, it is imperative that these types of services be integrated with financial services for youth entrepreneurs. Furthermore, organizations providing business support and financial services should seek to link youth entrepreneurs to local trade unions and business associations, in order to help them build their networks. Targeted services for female entrepreneurs, with a particular focus on business information and peer-topeer mentoring systems, should also be developed in order to encourage female youth to start businesses.

Combining financial services with business information, training, and networking in a single package can help create the supportive environment needed to encourage youth entrepreneurship in Egypt. In the early stages of a new venture, this integrated package of support can help ensure the success of a nascent business. The knowledge that these services exist can also help reduce fear of failure among youth interested in starting a business, and perhaps reduce the sense that labormarket security necessarily means a formal waged job.
Attia, Sayed M. 2009. The Informal Economy as an Engine for Poverty Reduction and Development in Egypt. MPPRA Paper No. 13034. http://mpra. ub.uni-muenchen.de/13034.

Global Entrepreneurship Monitor (GEM). 2010. GEM Special Report: A Global Perspective on Entrepreneurship Education and Training.

International Development Research Center and Palestine Economic Policy Research Institute (IDRC and PEPRI). 2009. Global Entrepreneurship Monitor: GEM-MENA Regional Report 2009.

United Nations Development Program and the Institute of National Planning (UNDP and INP). 2010. Egypt Human Development Report 2010 Youth in Egypt: Building our Future.

\section{References}

Assaad, Ragui. 2008. "Unemployment and Youth Insertion in the Labor Market in Egypt." In The Egyptian Economy: Current Challenges and Future Prospects. Ed. Hana Khayr al-Din. Cairo: American University in Cairo Press. Pp. 133-178.

The Population Council confronts critical health and development issues-from stopping the spread of HIV to improving reproductive health and ensuring that young people lead full and productive lives. Through biomedical, social science, and public health research in 50 countries, we work with our partners to deliver solutions that lead to more effective policies, programs, and technologies that improve lives around the world. Established in 1952 and headquartered in New York, the Council is a nongovernmental, nonprofit organization governed by an international board of trustees.

\section{www.popcouncil.org}

(C) 2012 The Population Council, Inc. 